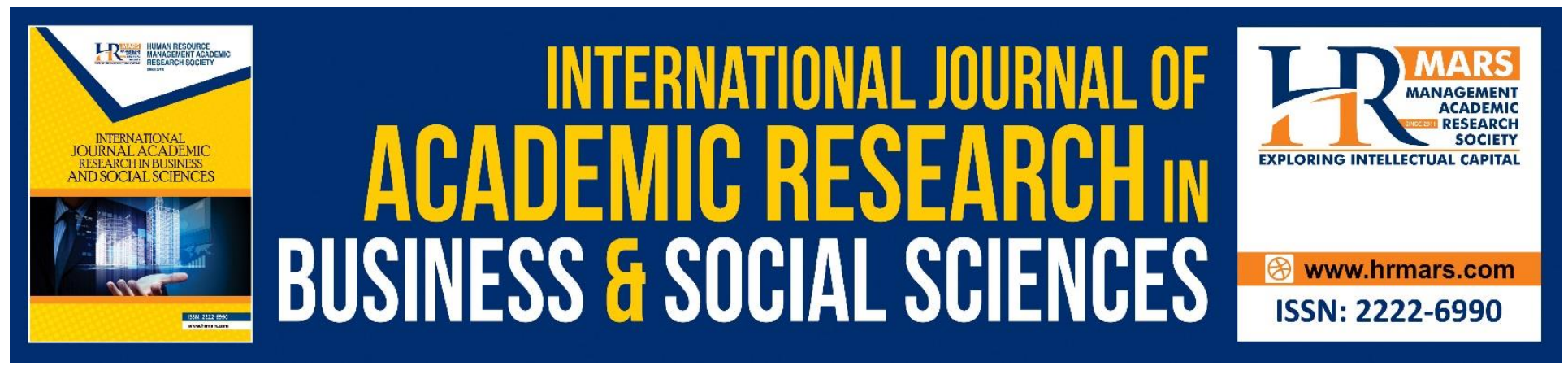

\title{
Innovation as a Mediator on the Assessment of Market Orientation, Training, Social Network, Access to Finance and Women Business Performance in the North-Western Nigeria: A Proposed Framework
}

Rahmat Magajiya Aliyu, Tunku Salha Binti Tunku Ahmad, Norshahrizan Binti Nordin \& Isah Mohammed Abdullahi

To Link this Article: http://dx.doi.org/10.6007/IJARBSS/v9-i1/5404 DOI: $10.6007 /$ IJARBSS/v9-i1/5404

Received: 08 Nov 2018, Revised: 30 Dec 2018, Accepted: 21 Jan 2019

Published Online: 29 Jan 2019

In-Text Citation: (Aliyu, Ahmad, Nordin, \& Abdullahi, 2019)

To Cite this Article: Aliyu, R. M., Ahmad, T. S. B. T., Nordin, N. B., \& Abdullahi, I. M. (2019). Innovation as a Mediator on the Assessment of Market Orientation, Training, Social Network, Access to Finance and Women Business Performance in the North-Western Nigeria: A Proposed framework. International Journal of Academic Research in Business and Social Sciences, 9(1), 366-379.

\section{Copyright: (C) 2019 The Author(s)}

Published by Human Resource Management Academic Research Society (www.hrmars.com) This article is published under the Creative Commons Attribution (CC BY 4.0) license. Anyone may reproduce, distribute, translate and create derivative works of this article (for both commercial and non-commercial purposes), subject to full attribution to the original publication and authors. The full terms of this license may be seen at: http://creativecommons.org/licences/by/4.0/legalcode

\section{Vol. 9, No. 1, 2019, Pg. 366 - 379}

Full Terms \& Conditions of access and use can be found at http://hrmars.com/index.php/pages/detail/publication-ethics 


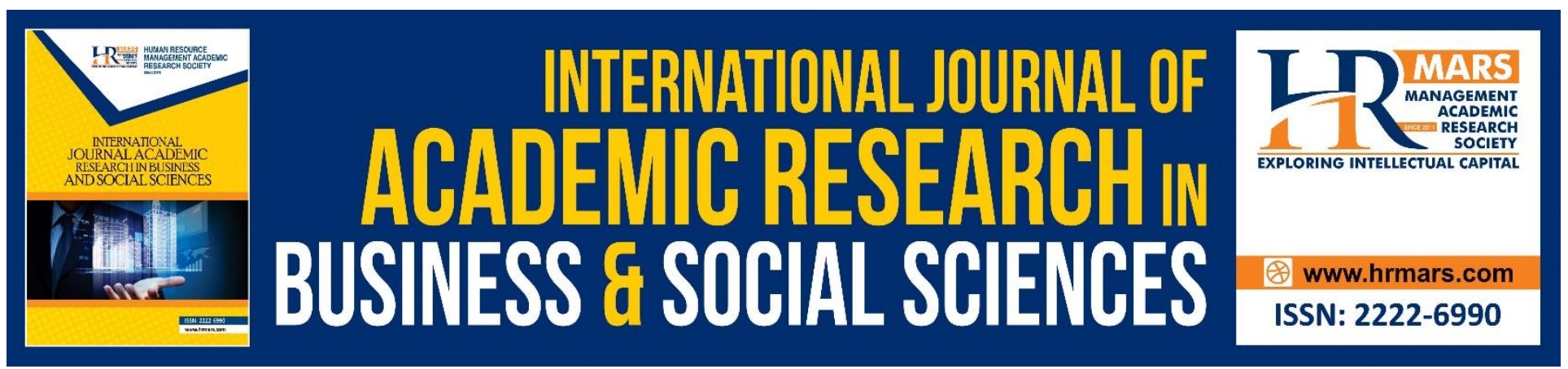

\title{
Innovation as a Mediator on the Assessment of Market Orientation, Training, Social Network, Access to Finance and Women Business Performance in the North-Western Nigeria: A Proposed framework
}

\author{
Rahmat Magajiya Aliyu', Tunku Salha Binti Tunku Ahmad² \\ Norshahrizan Binti Nordin ${ }^{3}$ and Isah Mohammed Abdullahi \\ Email: rahmatmagajiyaaliyu40@gmail.com,tsalha70@yahoo.com, \\ norshahrizan.nordin@gmail.com, isabdullahii136@ymail.com \\ School of Business Innovation and Technopreneurship; Universiti Malaysia Perlis.
}

\begin{abstract}
Studies in the field of entrepreneur business SMEs report to have contribute 46\% of Nigerian GDP and men contributed to the economic growth more than women counterpart while women constitute more than half of Nigeria population therefore, this study seek to proposal the mediating role of innovation on the influence of market orientation, training, social network, access to finance on women business performance with the inclusion of micro enterprise because women constituted more than three third of the population of micro businesses and the introduction of innovation as a mediator is to see how women can use modern technology in improving their business performance. Keywords: Market Orientation, Training, Social Network, Access To Finance And Innovation.
\end{abstract}

\section{INTRODUCTION}

In other words, women activities specifically in business empower them economically and enable them to contribute to the general development of the nation. Yet, women in the most parts of the developing world (including Nigeria) continue to face various forms of discriminations, which limit their opportunities to develop to their full potentials and they also face some difficulties in pursuit of enterprise success (Koko, Maishanu \& Hassan, 2017; Abubakar, 2013). Women entrepreneurs are indeed innovative by nature in an attempt to create economic value and satisfy family needs, they create businesses and exhibit entrepreneurial acumen. Indeed their contributions to the sustenance of families and economy of their respective communities are enormous. Furthermore, Ogujiuba, Fadila and Stiegler (2013) Koko et al. (2017) and Koko (2014) express the needs and relevance of encouraging women's access to finance as well as improving economic 
diversification and growth. The authors also stated that the empowerment of women could encourage and inspire development in a community.

Even though women entrepreneurs play a crucial role in the economic development of their families and countries, nevertheless, it has been revealed that they have lower performance in their business in contrasted to their male counterparts (Ogujiuba et al., 2013; Abdulkadir, Umar, Garba,. \& Ibrahim, 2012), as such lack of education or training, and social network affects their entrepreneurial performance (SMEDAN, 2013). According to Koko et al. (2017), women entrepreneurs in most developing countries lack easy access to finance for entrepreneurial activity while the rate of women involvement in the informal sector of the economy is higher than the male in Nigeria (Akinyi, 2009; Terungwa, 2012) This problem is due to inability to save because of poverty, low household income, and unemployment (Ogujiuba et al., 2013).

Women entrepreneurs, particularly in developing countries, have difficulty in accessing financial facilities for entrepreneurial activity and this lead to low business performance compared to men counterparts, While, the participation of women in informal sector of the economy is higher than males (Ike, 2017; Momoh, 2013). Women entrepreneurs in developing countries, Nigeria inclusive, are particularly saddled with certain peculiarities that hinder their ability to have access to finance within the society. Their cultural practice characterizes these impediments, for example, early marriage, male influence in every sphere, and low formal education they regard as an obstruction to women because the husbands are too busy to help at home even when the need arises. Furthermore, the male does not allow their wives to go out because of the strong religion and culture fact that limit women movement only with their husbands (Idris \& Agbim, 2015).

\section{MARKET ORIENTATION}

Market orientation Reveals an organisational culture that places the fulfillment of customer needs and wants at the center of business activities (Liao et al. 2011), (Didonet, Simmons, DiazVillavicencio \& Palmer, 2012) which leads to the achieving a superior performance. Customer Orientation According to a research by Narver and Slater (1990) Tzempelikos and Govnaris (2015) and Tomczak, Reinecke, \& Kuss, (2018), customer orientation is a significant element of MO, which refers to the capability of a business organisation to comprehend the needs of its prospective customer, with a view to providing the customers with a sustained benefit for their products and services. Competitor Orientation Narver and Slater (1990) and Baker and Sinkula (2015) explained that competitor orientation is moved by an organisation to understand both the strengths and weaknesses of its key competitors, as well as the ability to understand their competencies and strategies. Inter-Functional Coordination According to Narver and Slater (1990) and Tzempelikos et al (2015), it is vital to coordinate the firm resources to add value for target customers, a process that they referred to as "inter-functional coordination".

Over the time, professionals have acknowledged the fact that market orientation research is an important effect on the development of marketing knowledge (Kanagal, 2017; Kohli \& Jaworski, 1990). International studies in marketing management often concentrate on developed countries, rather than developing countries. In addition, marketing researchers have recognised this constraint and called for the extension of such research to an international context (Homburg \& Pflesser, 2000; Homburg, Jozic \& Kuehnl, 2017). Studies on market orientation about business have advocated that 
INTERNATIONAL JOURNAL OF ACADEMIC RESEARCH IN BUSINESS AND SOCIAL SCIENCES

Vol. 9, No. 1, Jan, 2019, E-ISSN: 2222-6990 @ 2019 HRMARS

organisations that are continually studying their competitors' actions and customers' needs will have a better understanding in combating their rivals as well as meeting the needs of their consumers (Ansah \& Chinomona, 2017; Wang, Chen \& Chen, 2017).

Previous studies confirm market orientation to have positive effects on business performance (Jogaratnam, 2017; Gilaninia, Taleghani, \& Talab, 2013).

\section{TRAINING}

Is art of bridging the gap between the current performance and the desired performance (Elnaga \& Imran, 2013) It refers to the entrepreneur's abilities to identify and tap entrepreneurial opportunity and the skill, to acquire knowledge (Rowland, Rowland, Hall, Hall, Altarawneh, \& Altarawneh, 2017), which could lead to business performance. Therefore in this study training is refers to the skill to acquired knowledge.

Women entrepreneurs in developing countries are lacking training (Ekpe, Mat \& Razak, 2016), and entrepreneurial activity is a source of human capital development that plays the role of providing an opportunity for learning, ability, attitudes, and skills to individuals. The impact of training in developing countries on women entrepreneurs' performance has not been addressed adequately in literature because most women are facing societal discriminations, poverty, and low educational level (Mtey \& Sulle, 2013; Abdulkadir et al., 2012). According to Abdulkadir et al. (2012), training is an important factor in the MSMEs as it provides women entrepreneurs with the abilities and practical experience required for business development. Literature shows that most of the micro-finance customers are lack of specialized skills in using the microfinance facilities. Therefore, they need training in order to use the microfinance facilities. On the other hand, most women entrepreneurs in developing countries are lacking prior business experience that is among the important factors for enterprise success (Idris \& Agbim, 2015).

Therefore, women entrepreneurs need training in using the microfinance facilities to further strengthen their business experience. Some literature suggested the need to study training on business performance in developing countries because of their low income and low educational background (Geordis \& Pitelis, 2016; Saks \& Smalley, 2014). Training is linked to education' and women entrepreneurs in developing nations are less educated if compared to women in developed nations (Ibru, 2009; Hameed, Hussin, Azeem, Arif \& Basheer, 2017). Previous studies confirm training to have positive impact on business performance (Chinomona, 2013; Saks \& Smalley, 2014; Aragon, Jimenez \& Valle, 2014). However, the utilisation of entrepreneurial opportunity is determined by the entrepreneur's level of knowledge or skills acquired and social networking through working experience (Idris \& Agbim, 2015).

\section{SOCIAL NETWORK}

Ahimbisibwe and Nangoli (2012) define social network as the number of social ties and network transitivity. In addition, Social Network refers to as systems of relationships between entrepreneurs and the outside world that are valuable to the small business.

The social network is vital to entrepreneurs in starting up, and growing business as such women entrepreneur is in developing countries are lacking social connections of sourcing information on accessing the micro-finance facilities (Zali, Schott, Kordnaeji \& Najafian, 2017; 
Ogunnaike \& Kehinde, 2013). Social network with others is carried out since the majority of entrepreneurs depend on the raw materials, information, knowledge or technology, in order to efficiently perform, develop and acceptable in the societies.

The social network provides a way in which significant information can be potentially attained cost-effectively. Equally, social networks are becoming popular in MSMEs as a result of the competitive advantage and ability to share resources and capabilities with other organisations by gaining economic of scale, reducing transaction costs, providing access to resources, obtain resources below the market price, identify new business opportunities, and secure legitimacy from external stakeholder (Ogunnaike \& Kehinde, 2013; Stam, Arzlanian \& Elfring, 2014).

Therefore, the social network can increase a business capital through the provision of access to information and human capital in improving productive activities (Stam et al., 2014) Previous studies have indicated that firm innovation performance plays a crucial role in determining the growth and competitiveness of an organisation (Chan-Kim \& Mauborgne, 2005; Lindic, Bavdaz, \& Kovacic, 2012). Social network is vital to entrepreneurs in starting up, and growing business as such women entrepreneur in developing nations are lacking social connections of sourcing information on accessing the micro-finance facilities (Anis \& Mohamed, 2012).

The social network was measured and found to have a positive influence on business performance (Anis \& Mohamed, 2012; Ahmed \& Saif, 2013; Surin \& Wahab, 2013; Ogunnaike \& Kehinde, 2013; Zaglia, Waiguny, Abfalter, \& Müller, 2015; Zali et al., 2012).

\section{ACCESS TO FINANCE}

According to Mazanai and Fatoki (2012), access to finance is defined as the availability of financial resources inform of internal resource, debt and equity for SMEs. Thus access to finance is the difference between SMEs demand for financial resources and supply of the necessary financial resources. Access to finance is defined by SMEDAN (2013) as the financial services provided by the financial institutions. Therefore, the study looks at the access to finance or financial resources as the accessibility for financial services and financial assets to SMEs (Aldamen, Duncan, Kelly, McNamara, \& Nagel, 2012).

It is noteworthy the enterprise success depends largely on the availability of funds and indigenous women entrepreneurs struggle hard to source these funds, which in the process may encounter many constraints that may inhibit their access to finance, which could eventually limit business growth (Magugui, Kogei, \& Chepkemei, 2014). The challenges facing women entrepreneurial are numerous. Women are faced with problems of accessing the finance, training, social network as well as legal and policy limitations (Milroy \& Liamas, 2013; Niethammer, 2013).

Studies on the challenges encountered by women entrepreneurs when accessing finance are insufficient and scanty, previous researchers focus more on the role of finance on enterprise growth and quantum finance accessed (Idris \& Agbim, 2015). Consequently, women do not have access to finance as much as their men counterpart because of harmful myths and stereotypes associated with gender as a result of lack of financial education and income history resulting in lower credit scores and absence of social networks in accessing and monitoring of capital (Abubakar, 2013).

However, the need to enhance the business participation of women in developing countries in order to promote and maximize their contribution to economic development becomes obvious. 
INTERNATIONAL JOURNAL OF ACADEMIC RESEARCH IN BUSINESS AND SOCIAL SCIENCES

Vol. 9, No. 1, Jan, 2019, E-ISSN: 2222-6990 @ 2019 HRMARS

Whether women engage in micro, small or medium production, formal or informal sectors, women entrepreneurial activities are not only a catalyst for economic growth but play a significant and positive role within the immediate social environment.

\section{INNOVATION}

According to Covin and Mille (2014), it is the ability of a business enterprise to be up to date with a new idea, new technologies and improved creative processes to provide products. The research is narrowed only to incremental innovation since small and medium enterprise emphases more on the incremental innovation more than the essential innovation of involving service, product, and process innovations (Baregheh, Rowley, Sambrook \& Davies, 2012). For a business organisation to be innovative, it must encourage the introduction of new ideas, creativity, testing and creative response to situations that will result in new products and new ways of doing things (Halim, Ahmad, Ramayah, \& Hanifah,, 2014), while innovation is the ability and strength of a business enterprise to initiate new measurement of actualizing the new products and the ideas to produce (Covin \& Mille, 2014).

Innovation signifies the combination of technology, knowledge, and entrepreneurship in order to increase organisational productivity (Janeway, 2012). There is increasing evidence from the literature that innovation plays a vital role in shaping the growth and competitiveness of firms in a country (Forsman \& Temel, 2011; Martinez-Conesa, Soto, Acosta \& Palacios-Manzano, 2017). Innovation has become a pre-requisite and linked to the growth, performance, competitiveness, increase in profit as well as the long-term survival of the firm (Jimenez- Jimenez \& Sanz-Valle, 2011; Pletcher \& Mann, 2013). In the works of Basu (2013) and Kogabayev and Maziliauskas (2017), innovation was defined as the implementation of knowledge or activity that is newly acquired by an organisation.

The implementation of innovation is termed as a practice that encapsulates development, generation and deployment of innovation concepts or activities. Furthermore, the researchers maintained that innovation is regarded as an "agent for change"; where it is used as a response to an external stimulus or used as a defensive measure to impact on the environment. In addition, according to Donate and Pablo (2015), innovation does not stop at mere implementation of new ideas, but signifies the adaptation of novel information and practices, which could lead to ability by the establishments to design new ideas and deploy them to improvise in creating new products, services, business processes and strategies. Also, Drucker (2014) maintained that there exist seven basic sources of innovation prospects, which include the unanticipated, inconsistencies, process requirements, market and industry structures, demography, changes in conception and new ideas. In summary, innovation does not need to be too technical in its nature.

Therefore, a more precise definition of innovation is the deployment of practical skills and techniques, which has the effect of making both minor and major changes to products, processes, and services, as well as resulting in the creation of a novelty for the organisation. The novelty is expected to add value to the customers as well as contribute to the organisation's knowledge stockpile (Dooley \& O'Sullivan, 2016; Dooley, Kenny \& Osullivav, 2017). In this study, innovation is limited to the incremental product, service and process innovation. This is because the MSME's innovation activities are more of ad-hoc nature or project-driven. Furthermore, the MSMEs are 
frequently constrained regarding finances (Hoffman, Parejo, Bessant, \& Perren, 1998; .Ettahri \& Laachach, 2016; Koko, 2014; Ogujiuba et al., 2013) In addition, the MSMEs are more probable to emphasis on "incremental innovation", as suggested by Oke (2007) and Boachie-Mensah and Acquah (2015). The following subsections explained the differences between product, service and process innovation in details.

Product Innovation The concept of "product innovation" or "service innovation" denotes changes made by an organisation to the finished products or services (Daniel Sherman, Berkowitz \& Souder, 2005; Jugend, De-Silva, Oprime \& Pimenta, 2015). Further, product innovation refers to the creation of a new product category or execution of minor modifications to the existing products, for the customers' benefit. Service Innovation Innovations regarding business services have promoted the global economy owing to dynamic nature of businesses and rapid growth (McDermott \& Prajogo, 2012). Service innovation does not necessitate physical product, thus may result to difficulties, concerning how innovations could be defined, as well as measured. Process Innovation Process innovation refers to the changes accorded to the manner in which products or services are produced or delivered (Cooper, 1998; Ferreira, Fernandes, Alves \& Raposo, 2015; Piening \& Salge, 2015). Process innovation has been defined, according to some studies, as tools, devices and knowledge in through put skill, which intermediates between the inputs and the outputs (Gopalakrishnan \& Damanpour, 1997; Langley, Smallman, Tsoukas \& Vende Ven, 2013).

Previous studies have examined the mediating role innovation on the relationship between market orientation, training, social network,access to finance to probe the effects of market orientation (Prifti and Alimehmeti ,2017: Lim, Lim, Darley, Darley, Marion, \& Marion, 2017: Grissemann, Plank and Brunner-Sperdin ,2013), training (Rosli and Mahmood, 2013) social network (Palacios-Marques, Merigo and Soto-Acosta , 2015)and access to finance on business performance (.Lee, Sameen, and Cowling , 2015: Lee, Dedahanov and Rhee , 2015) Some of the relevant literatures are described below.

More so, it is important to note that without analyzing the mediating variable, it is difficult to evaluate the link between market orientations, training, social network, access to finance and business performance on why they effects each other under what condition of indirect effects (Baron \& Kenny, 1986; Hayes, 2009). The followings are the past studies that used innovation as a mediator (Davoudi, Fartash, Venera, Asiya, Rashad, Anna and Zhann, 2018: Zhou, Zhou, Feng and Jiang, 2017: Mahmoud, Blankson, Owusu-Frimpong, Nwankwo and Trang, 2016: Sharma, Davcik and Pillai, 2016). Generally, all findings of these studies supported the notion that innovation can improve the performance of women MSMEs.

\section{Proposed Research Framework}

Building on the foregoing discussion and literature review, this paper proposes a conceptual framework as illustrated in Figure 1. 


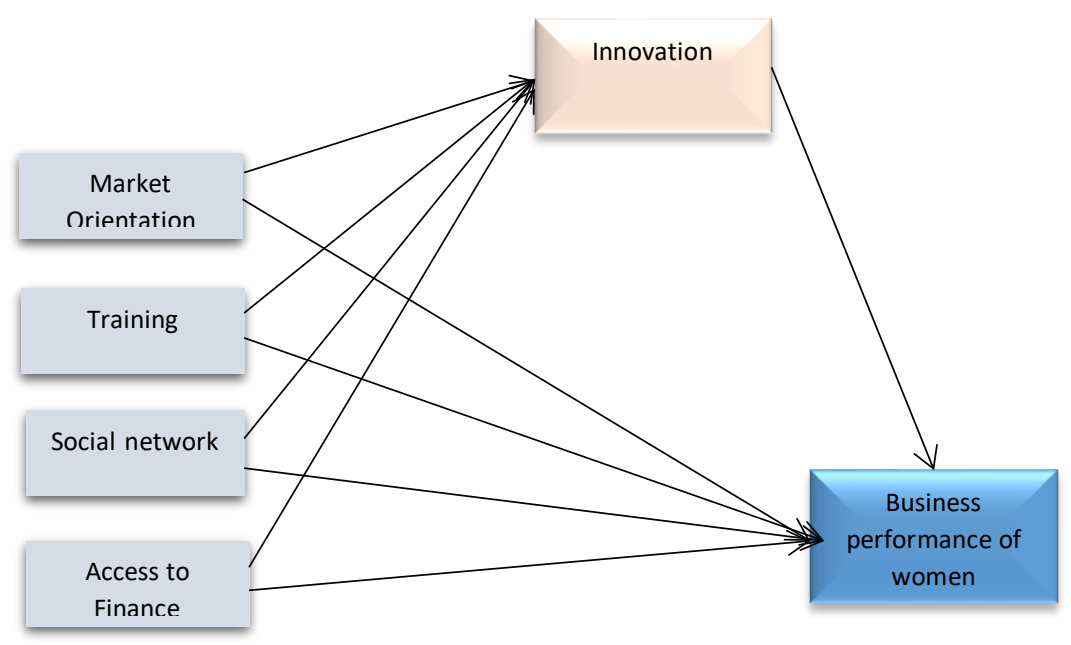

Figure 1: Proposed research framework

The proposed conceptual framework shows the mediating role of innovation on effect of Market Orientation, Training, Social network, Access to finance and business performance of women. Based on the Figure 1 above innovation is a mechanism of improving the women business performance which will be the conceptual or practical contribution of the study.

\section{METHODOLOGY}

The present study will use SPSS for coding the questionnaire and PLS-SEM for data analysis. The study will employ the use of social network theory for social network while pecking order theory will be used for access to finance and lastly research based theory will be use to analyse market orientation, business performance and innovation as a mediator.

\section{CONCLUSION}

The present study will examined the impacts of MO, TR, SN, AF, and Business performance of women and also the mediating effects of innovation on $\mathrm{MO}, \mathrm{TR}, \mathrm{SN}, \mathrm{AF}$ and Business performance of women in a newer context and setting. The findings of this study will provide important implications to theoretical, practical and methodological contributions.

In summary, this study will contribute to women entrepreneurs and the understanding of owner/managers of women MSMEs. Women MSME entrepreneurs may likely have a variety of thoughts and actions that will possibly assist them in Running their business with the required time and attention as such it will give room for improvement and better performance.

In conclusion, issues of the business performance of women MSMEs will remain an important agenda for political leaders, managers and employees of, academicians, researchers and community at large. It is believed that the women MSMEs performance of owner-managers, and entrepreneurs will provide a rich backdrop against which women business will still have room to improve the Nigerian GDP. 
INTERNATIONAL JOURNAL OF ACADEMIC RESEARCH IN BUSINESS AND SOCIAL SCIENCES

Vol. 9, No. 1, Jan, 2019, E-ISSN: 2222-6990 @ 2019 HRMARS

\section{REFERENCES}

Abdulkadir, F.I., Umar, S., Garba, B.I. \& Ibrahim S.H. (2012). The impact of microfinance banks on women entrepreneurial development in Kaduna metropolis. Microeconomics and Macroeconomics, 1(3), 28-38.

Abubakar, k. m. (2013). Capital Access Strategies and Enterprise Growth: A Study of Selected Indigenous Women Entrepreneurs in Sokoto Metropolis, Nigeria. Sokoto Journal of Management Studies, 4(1), 25-38

Ahimbisibwe, A., \& Nangoli, S. (2012). Project communication, individual commitment, social networks, and perceived project performance. Journal of African Business, 13(2), 101-114.

Ahmed, M. H. U., \& Saif, A. N. M. (2013). Necessity of capacity building before taking microcredit: Poor women perspective of Bangladesh. Journal of Business Management and Social Sciences Research, 2(10), 27-32.

Akinyi, J. (2009). The role of microfinance in empowering women in Africa. Retrieved January 10, 2010, from The African Executive Magazinehttp://www.google.com.

Aldamen, H., Duncan, K., Kelly, S., McNamara, R., \& Nagel, S. (2012). Audit committee characteristics and firm performance during the global financial crisis. Accounting \& Finance, 52(4), 9711000.

Anis, O. \& Mohamed, F. (2012). How entrepreneurs identify opportunities and access to external finacing in Tunisian's microenterprises? African Journal of Business Management, 6(12), 46354647.

Ansah, M. O., \& Chinomona, R. (2017). Analysis of Market Orientation on Business Performance in the Multinational Service Industries. Journal of Social Sciences

Aragón, M. I. B., Jiménez, D. J., \& Valle, R. S. (2014). Training and performance: The mediating role of organisational learning. BRQ Business Research Quarterly, 17(3), 161-173.

Baker, W. E., \& Sinkula, J. M. (2015). Maintaining Competitive Advantage Through Organizational Unlearning. In Proceedings of the 1999 Academy of Marketing Science (AMS) Annual Conference (pp. 206-209). Springer, Cham.

Baregheh, A., Rowley, J., Sambrook, S., \& Davies, D. (2012). Innovation in food sector SMEs. Journal of Small Business and Enterprise Development, 19(2), 300-321.

Basu, S. (2013). Knowledge evolution and innovation linkages: evidences from Indian state owned enterprise. International Journal of Business Excellence, 6(4), 377-392.

Boachie-Mensah, F., \& Acquah, I. S. (2015). The effect of innovation types on the performance of small and medium-sized enterprises in the Sekondi-Takoradi Metropolis. Archives of Business Research, 3(3).

Chan Kim, W., \& Mauborgne, R. (2005). Value innovation: a leap into the blue ocean. Journal of business strategy, 26(4), 22-28.

Chinomona, R. (2013). Business owner's expertise, employee skills training and business performance: A small business perspective. Journal of Applied Business Research, 29(6), 1883.

Cooper, J. R. (1998). A multidimensional approach to the adoption of innovation. Management decision, 36(8), 493-502. 
INTERNATIONAL JOURNAL OF ACADEMIC RESEARCH IN BUSINESS AND SOCIAL SCIENCES

Vol. 9, No. 1, Jan, 2019, E-ISSN: 2222-6990 @ 2019 HRMARS

Covin, J. G., \& Miller, D. (2014). International entrepreneurial orientation: Conceptual considerations, research themes, measurement issues, and future research directions. Entrepreneurship Theory and Practice, 38(1), 11-44.

Daniel Sherman, J., Berkowitz, D., \& Souder, W. E. (2005). New product development performance and the interaction of cross-functional integration and knowledge management. Journal of Product Innovation Management, 22(5), 399-411.

Davoudi, S. M. M., Fartash, K., Venera, G. Z., Asiya, M. B., Rashad, A. K., Anna, V. B., \& Zhanna, M. S. (2018). Testing the Mediating Role of Open Innovation on the Relationship between Intellectual Property Rights and Organizational Performance: A Case of Science and Technology Park. EURASIA Journal of Mathematics Science and Technology Education, 14(4), 1359-1369.

Didonet, S., Simmons, G., Díaz- Villavicencio, G., \& Palmer, M. (2012). The relationship between small business market orientation and environmental uncertainty. Marketing Intelligence \& Planning, 30 (7), 757-779.

Donate, M. J., \& de Pablo, J. D. S. (2015). The role of knowledge-oriented leadership in knowledge management practices and innovation. Journal of Business Research, 68(2), 360-370.

Dooley, L., \& O'Sullivan, D. (2016). Inter-organisational Innovation: Collaborative Breadth and Depth within the low-technology SME sector. In ISPIM Conference Proceedings (p. 1). The International Society for Professional Innovation Management (ISPIM).

Dooley, L., Kenny, B., \& O'Sullivan, D. (2017). Innovation capability development: case studies of small enterprises in the LMT manufacturing sector. Small Enterprise Research, 24(3), 233-256.

Drucker, P. (2014). Innovation and entrepreneurship. Routledge.

Ekpe, I. Razak, R. C., Ismail, M., \& Abdullah, Z. (2016). Entrepreneurial skill acquisition, psycho-social factors and youth's self-employment in Malaysia. Journal of Entrepreneurship Education, 19(2), 93-101.

Elnaga, A., \& Imran, A. (2013). The effect of training on employee performance. European Journal of Business and Management, 5(4), 137-147.

Ettahri, Y., \& Laachach, A. (2016). Specific Financial Constraints of Innovative Companies: Theoretical Approach. Journal of Modern Accounting and Auditing, 12(11), 556-566.)

Ferreira, J. J., Fernandes, C. I., Alves, H., \& Raposo, M. L. (2015). Drivers of innovation strategies: Testing the Tidd and Bessant (2009) model. Journal of Business Research, 68(7), 1395-1403.

Forsman, H. \& Temel, S. 2011. Innovation and business performance in small enterprises: An enterprise-level analysis. International Journal of Innovation Management, 15(3):641-665.

Georgiadis, A., \& Pitelis, C. N. (2016). The Impact of Employees' and Managers' Training on the Performance of Small-and Medium-Sized Enterprises: Evidence from a Randomized Natural Experiment in the UK Service Sector. British Journal of Industrial Relations, 54(2), 409-421.

Gilaninia, S., Taleghani, M., \& Talab, S. M. (2013). Market orientation and business performance. Singaporean. Journal of Business, Economics and Management Studies, 1(11), 13-17.

Grissemann, U., Plank, A., \& Brunner-Sperdin, A. (2013). Enhancing business performance of hotels: The role of innovation and customer orientation. International Journal of Hospitality Management, 33, 347-356. 
Halim, H. A., Ahmad, N. H., Ramayah, T., \& Hanifah, H. (2014). The growth of innovative performance among SMEs: Leveraging on organisational culture and innovative human capital. Journal of Small Business and Entrepreneurship Development, 2(1), 107-125.

Hameed, W. U., Hussin, T., Azeem, M., Arif, M., \& Basheer, M. F. (2017). Combination of microcredit and micro-training with mediating role of formal education: A micro-enterprise success formula. Journal of Business and Social Review in Emerging Economies, 3(2), 285-291.

Hoffman, K., Parejo, M., Bessant, J., \& Perren, L. (1998). Small firms, R\&D, technology and innovation in the UK: a literature review. Technovation, 18(1), 39-55.

Homburg, C., \& Pflesser, C. (2000). A multiple-layer model of market-oriented organisational culture: Measurement issues and performance outcomes. Journal of marketing research, 37(4), 449462.

Homburg, C., Jozić, D., \& Kuehnl, C. (2017). Customer experience management: toward implementing an evolving marketing concept. Journal of the Academy of Marketing Science, 45(3), 377-401.

Ibru, C. (2009). Growing microfinance through new technologies. Federal University of Technology, Akure, Nigeria.

Idris, A. J., \& Agbim, K. C. (2015). Micro-credit as a strategy for poverty alleviation among women entrepreneurs in Nasarawa State, Nigeria. Journal of Business Studies Quarterly, 6(3), 122.

Ike, P. C. (2013). Analysis of impact of microfinance services on business performance of small scale women entrepreneurs in Enugu State, Nigeria. Asian Journal of Agriculture and Rural Development, 3(6), 424.

Janeway, W. H. (2012). Doing capitalism in the innovation economy: markets, speculation and the state. Cambridge University Press.

Jiménez-Jiménez, D., \& Sanz-Valle, R. (2011). Innovation, organizacional learning, and performance.Journal of Business Research, 64 (4), 408-417.

Jogaratnam, G. (2017). How organizational culture influences market orientation and business performance in the restaurant industry. Journal of Hospitality and Tourism Management, 31, 211-219.

Jugend, D., da Silva, S. L., Oprime, P. C., \& Pimenta, M. L. (2015). Organizational issues for integration of high-technology in new product development: framework proposal and case studies in Brazilian companies. Innovation, 17(2), 217-231.

Kanagal, N. B. (2017). Development of Market Orientation for Marketing Strategy Formulation. International Journal of Marketing Studies, 9(4), 54.

Kogabayev, T., \& Maziliauskas, A. (2017). The definition and classification of innovation. HOLISTICAJournal of Business and Public Administration, 8(1), 59-72.

Kohli, A. K., Jaworski, B. J., \& Kumar, A. (1993). MARKOR: a measure of market orientation. Journal of Marketing research, 467-477.

Koko, M. A, Maishanu, M. M, \& Hassan, A. (2017). Women entrepreneurs' accessibility to growth capital and socio-economic development in Sokoto State, Nigerian. IOSR Journal of businesS \& Management, 19(5) 69-75

Koko, M. A. (2013). Capital Access Strategies and Enterprise Growth: A Study of Selected Indigenous Women Entrepreneurs in Sokoto Metropolis, Nigeria. Journal of Management Studies, 1-38. 
INTERNATIONAL JOURNAL OF ACADEMIC RESEARCH IN BUSINESS AND SOCIAL SCIENCES

Vol. 9, No. 1, Jan, 2019, E-ISSN: 2222-6990 @ 2019 HRMARS

Koko, M. A. (2014). Enterprise Characteristics and Accessibility to Growth Capital: Study of Indigenous Women's Enterprises in Sokoto, Nigeria. World, 4(2).

Langley, A. N. N., Smallman, C., Tsoukas, H., \& Van de Ven, A. H. (2013). Process studies of change in organization and management: Unveiling temporality, activity, and flow. Academy of Management Journal, 56(1), 1-13.

Lee, D. H., Dedahanov, A. T., \& Rhee, J. (2015). Moderating role of external networks and mediating effect of innovation performance on the relationship between technology orientation and firm performance. Asian Journal of Technology Innovation, 23(3), 321-334.

Lee, N., Sameen, H., \& Cowling, M. (2015). Access to finance for innovative SMEs since the financial crisis. Research policy, 44(2), 370-380.

Liao, S. H., Chang, W. J., Wu, C. C., \& Katrichis, J. M. (2011). A survey of market orientation research (1995-2008). Industrial marketing management, 40(2), 301-310.

Lim, J. S., Lim, J. S., Darley, W. K., Darley, W. K., Marion, D., \& Marion, D. (2017). Market orientation, innovation commercialization capability and firm performance relationships: the moderating role of supply chain influence. Journal of Business \& Industrial Marketing, 32(7), 913-924.

Lindic, J., Bavdaz, M., Kovacic, H. (2012). Higher Growth through the Blue Ocean Strategy: Implications for Economic Policy. Research Policy, 41(5). DOI: 10.1016/j. respol.2012.02.010.

Magugui, C. K., Kogei, J. K., \& Chepkemei, A. (2014). Microfinance in the achievement of millennium development goals: A case of Koilot division, Nandei County, Kenya. International Journal of Economics, Commerce and Management, 2(8), 1-7.

Mahmoud, M. A., Blankson, C., Owusu-Frimpong, N., Nwankwo, S., \& Trang, T. P. (2016). Market orientation, learning orientation and business performance: The mediating role of innovation. International Journal of Bank Marketing, 34(5), 623-648.

Martinez-Conesa, I., Soto-Acosta, P., \& Palacios-Manzano, M. (2017). Corporate social responsibility and its effect on innovation and firm performance: An empirical research in SMEs. Journal of cleaner production, 142, 2374-2383.

Mazanai, M., \& Fatoki, O. (2012). Access to finance in the SME sector: A South African perspective. Asian Journal of Business Management, 4(1), 58-67.

McDermott, C. M., \& Prajogo, D. I. (2012). Service innovation and performance in SMEs. International Journal of Operations \& Production Management, 32(2), 216-237.

McDermott, C. M., \& Prajogo, D. I. (2012). Service innovation and performance in SMEs. International Journal of Operations \& Production Management, 32(2), 216-237.

Milroy, L., \& Llamas, C. (2013). Social networks. The handbook of language variation and change, 407427.

Momoh, I. (2013). Creating a database for Nigerian MSMEs. Business Day.

Mtey, K. P. F. \& Sulle, A. (2013). The role of education in poverty reduction in Tanzania. Global Advanced Research Journal of Educational Research and Review, 2(1), 006-014.

Niethammer, C. (2013). Women, entrepreneurship and the opportunity to promote development and business. Brookings Blum Roundtable Policy Brief, 37.

Ogujiuba K, Fadila\&Stiegler (2013). "Challenges of Microfinance Access in Nigeria: Implication for Entrepreneurship Development". Mediterranean Journal of Social Science. 4 (6) 
Ogunnaike, O., \& Kehinde, O. J. (2013). Social networking and business performance: The case of selected entrepreneurs in Ota, Nigeria. Journal of Business Administration and Management Sciences Research, 2(5), 116-122.

Oke, A. (2007). Innovation types and innovation management practices in service companies. International Journal of Operations \& Production Management, 27(6), 564-587.

Palacios-Marqués, D., Merigó, J. M., \& Soto-Acosta, P. (2015). Online social networks as an enabler of innovation in organizations. Management Decision, 53(9), 1906-1920.

Piening, E. P., \& Salge, T. O. (2015). Understanding the antecedents, contingencies, and performance implications of process innovation: A dynamic capabilities perspective. Journal of Product Innovation Management, 32(1), 80-97.

Pletcher, C., \& Mann, R. (2013). Innovation Levers: Keys to Business Success in a DifficultEconomyRetrievedfromhttp://www.sopheon.com/NEWSEVENTS/inKNOWvationsNe wsletter

Prifti, R., \& Alimehmeti, G. (2017). Market orientation, innovation, and firm performance-an analysis of Albanian firms. Journal of Innovation and Entrepreneurship, 6(1), 8.

Rosli, M. M., \& Mahmood, R. (2013). Moderating effects of human resource management practices and entrepreneur training on Innovation and small-medium firm performance. Journal of Management and Strategy, 4(2), 60.

Rowland, C. A., Rowland, C. A., Hall, R. D., Hall, R. D., Altarawneh, I., \& Altarawneh, I. (2017). Training and development: challenges of strategy and managing performance in Jordanian banking. EuroMed Journal of Business, 12(1), 36-51.

Saks, A. M., \& Burke-Smalley, L. A. (2014). Is transfer of training related to firm performance?. International Journal of Training and Development, 18(2), 104-115.

Sharma, P., Davcik, N. S., \& Pillai, K. G. (2016). Product innovation as a mediator in the impact of R\&D expenditure and brand equity on marketing performance. Journal of Business Research, 69(12), 5662-5669.

Smedan, \& National Bureau of Statistics (NBS) (2013). Survey report on Micro, Small, and Medium Enterprises (MSMES) in Nigeria. Abuja: Small and Medium Enterprises Development Agency of Nigeria. National MSME Collaborative Survey, NBS and SMEDAN, Abuja.

Stam, W., Arzlanian, S., \& Elfring, T. (2014). Social capital of entrepreneurs and small firm performance: A meta-analysis of contextual and methodological moderators. Journal of Business Venturing, 29(1), 152-173.

Surin, E. F., \& Ab Wahab, I. (2013). The effect of social network on business performance in established manufacturing small and medium enterprises (SMEs) in Malaysia. International Proceedings of Economics Development and Research, 67, 55.

Terungwa, A. (2012). Risk management and insurance of small and medium scale enterprises (SMEs) in Nigeria. International Journal of Finance and Accounting, 1(1), 8-17.

Tomczak, T., Reinecke, S., \& Kuss, A. (2018). Introduction. In Strategic Marketing (pp. 1-18). Springer Gabler, Wiesbaden.

Tzempelikos, N., \& Gounaris, S. (2015). Key account management orientation and its impact on company's performance-an empirical study. In the Sustainable Global Marketplace (pp. 4447). Springer, Cham. 
Wang, Z., \& Kim, H. G. (2017). Can social media marketing improve customer relationship capabilities and firm performance? Dynamic capability perspective. Journal of Interactive Marketing, 39, 15-26.

Zaglia, M. E., Waiguny, M. K., Abfalter, D., \& Müller, J. (2015). The influence of online social networks on performance of small and medium enterprises: an empirical investigation of the online business to business network XING. International Journal of Entrepreneurial Venturing, 7(1), 1-23.

Zali, M. R., Schott, T., kordnaeij, A., \& Najafian, M. (2012).Role of social network in business performance: moderating effect of role model and entrepreneurial motivation (some evidences of gem data in iran, croatia and denmark).

Zhou, S. S., Zhou, A. J., Feng, J., \& Jiang, S. (2017). Dynamic capabilities and organizational performance: The mediating role of innovation. Journal of Management \& Organization, 117. 